\title{
Clonal Fidelity of Micropropagated Psidium guajava L. Plants Using Microsatellite Markers
}

\author{
Bernessa Rawls ${ }^{1}$, Karen Harris-Shultz ${ }^{2}$, Sadanand Dhekney ${ }^{3}$, Ivis Forrester ${ }^{4}$, Viji Sitther ${ }^{5}$ \\ ${ }^{1}$ Feagin Mill Middle School, Warner Robins, GA, USA \\ ${ }^{2}$ USDA Crop Genetics and Breeding Research Unit, Tifton, GA, USA \\ ${ }^{3}$ Sheridan Research and Extension Center, University of Wyoming, Sheridan, WY, USA \\ ${ }^{4}$ School of Community Health and Policy, Morgan State University, Baltimore, MD, USA \\ ${ }^{5}$ Department of Biology, Morgan State University, Baltimore, MD, USA \\ Email: viji.sitther@morgan.edu
}

Received 22 August 2015; accepted 20 September 2015; published 23 September 2015

Copyright (C) 2015 by authors and Scientific Research Publishing Inc.

This work is licensed under the Creative Commons Attribution International License (CC BY). http://creativecommons.org/licenses/by/4.0/

(c) (i) Open Access

\section{Abstract}

Micropropagation of Psidium guajava L. (guava) is a viable alternative to currently adopted techniques for large-scale plant propagation of commercial cultivars. Assessment of clonal fidelity in micropropagated plants is the first step towards ensuring genetic uniformity in mass production of planting material. In the present study, 31 plants of guava cultivar "Lucknow 49" regenerated by micropropagation were tested for genetic fidelity by comparing them to the mother plant from which explant material was obtained. Efficient rooting of in vitro proliferated shoots was obtained by culture on $1 / 2$ strength MS medium supplemented with either $9.8 \mu \mathrm{M}$ indole butyric acid (IBA) or $11.4 \mu \mathrm{M}$ indole acetic acid (IAA). Leaf samples of 31 regenerated plants were compared to the mother plant using 17 simple sequence repeat (SSR) markers. While 16 SSRs detected the same allele, locus mPgCIR07 detected slight differences, where six micropropagated plants were 1 bp smaller (152 bp) than the parental genotype (153 bp). Differences in leaf tissues for anthocyanin pigmentation were also noted among micropropagated plants. Results of the study indicated efficient rooting of "Lucknow-49" cultivar for rapid propagation of planting material, and revealed that micropropagated plants were identical for 16 of the 17 loci examined. Although most mutations induced by tissue culture may not have an effect on phenotype, the possibility that novel phenotypes can be generated in a commercial setting exists.

\section{Keywords}

Genetic Stability, Guava, Simple Sequence Repeats, Tissue Culture 


\section{Introduction}

Guava (Psidium guajava L.), one of the most valued crop plants, is grown in tropical and subtropical regions all over the world, with Mexico, Brazil, India, and Thailand being the largest producers [1]. The fruit is an excellent source of ascorbic acid, vitamin A, dietary fiber, iron, phosphorus, calcium, thiamin, and niacin [2] [3]. An increasing awareness of the health benefits of guava has resulted in an increased demand for the fruit with a subsequent increase in acreage and production. For instance, guava production in Hawaii, the largest producer of guava in the United States, grew from 1.3 million pounds in 2010 to 1.9 million pounds in 2011 [4]. The demand in expanding guava cultivation has increased the need for production of uniform planting material with high yield, good fruit quality, disease resistance, long fruit shelf life, and high nutrient content.

Guava is commercially propagated by seed while vegetative/asexual propagation by cuttings and layering is practiced on a limited scale. Since guava is an open pollinated species, reaching up to 35\% out-crossing [5], seeds that are not true-to-type are inevitably produced. Although clonal material can be obtained by vegetative propagation, these methods are not commercially viable due to the cumbersome nature of the processes and the absence of a taproot in vegetatively propagated plants [6]. Micropropagation serves as a viable alternative to seed propagation as it enables rapid propagation of elite stock cultivars in a relatively short period of time [7]. Genetic uniformity of micropropagated plants is a prerequisite for production of quality plant material. However, the use of plant growth regulators such as auxins induces somaclonal variation during the culture process ultimately leading to genetic variation in regenerated plants [8] [9]. Even at optimal levels, frequent transfers of cultures during micropropagation can result in genetic variation, thus questioning the clonal fidelity of regenerated plants. In order to make this technology commercially viable, it is important to verify that plants obtained by micropropagation are true-to-type to the parent plant from which they were derived.

Several molecular markers such as RAPD, ISSR and RFLP-ISSR have been used to detect genetic uniformity and identify any potential somaclonal variation in plants produced through micropropagation [10] [11]. Of these, simple sequence repeats (SSRs) have a distinctive advantage as they are co-dominant markers that produce reproducible results. Microsatellite markers for P. guajava $(2 n=2 x=22)$ have been developed using genomic libraries of the species for the simple sequence repeats $(G A)_{n}$ and $(G T)_{n}$ [12]. These SSRs were very efficient in the determination of genetic diversity among guava cultivars [13] [14].

Among the commercial guava cultivars, "Lucknow-49", commonly known as "Sardar", is a high yielding cultivar with fruit that has few seeds and a sweet pleasant flavor. With high vitamin $\mathrm{C}$ and total soluble solids of juice at 12.5 percent, it is widely used for commercial cultivation [15]. Additionally, it is resistant to the guava fruit fly, thus making it an ideal selection for growers [16]. So far, in vitro rooting of micropropagated shoots and clonal fidelity of micropropagated plants for "Lucknow 49" have not been optimized. The objectives of the present study were to establish efficient rooting of shoot cultures for "Lucknow-49" and test genetic fidelity of regenerated plants using microsatellite markers.

\section{Materials and Methods}

\subsection{Explant Material}

Seed material of guava cultivar "Lucknow 49" was obtained from a seven year old tree growing in a greenhouse. Seeds were surface sterilized in 70\% ethanol for $1 \mathrm{~min}$, washed in $10 \%$ (v/v) commercial bleach solution for 15 min and then rinsed three times, 5 min each, in sterile distilled water. Seeds were then germinated on MS medium [17] supplemented with $3 \%$ sucrose, $2.5 \mathrm{~g} \cdot \mathrm{L}^{-1}$ phytagel, $1.0 \mathrm{ml} \cdot \mathrm{L}^{-1}$ plant preservation mixture (Plant Cell Technology, Inc., Washington DC) and $0.4 \mu \mathrm{M}$ 6-benzylaminopurine (BA). Test tubes were incubated in the dark at $25^{\circ} \mathrm{C} \pm 2^{\circ} \mathrm{C}$ for three weeks following which the seedlings were maintained under a $16 \mathrm{~h}$ photoperiod (50 $\mu \mathrm{mol} \cdot \mathrm{m}^{-2} \cdot \mathrm{s}^{-1}$ ) for 5 - 6 weeks. Two nodal explants from a single seedling were transferred to MS medium supplemented with $8.8 \mu \mathrm{M}$ BA and $9.3 \mu \mathrm{M}$ kinetin (KIN) for shoot proliferation. Cultures were maintained as described previously [18]. After shoot establishment, explants were grown in G7 Magenta boxes (Magenta Corporation, Chicago, IL, USA.) containing $50 \mathrm{ml}$ MS medium for two weeks prior to root induction.

\subsection{Rooting of in Vitro Shoots}

Two cm long shoots were excised and transferred into test tubes containing $10 \mathrm{~mL} 1 / 2$ strength MS medium supplemented with varying levels of indole acetic acid (IAA), indolebutryic acid (IBA), and naphthaleneacetic 
acid (NAA) to induce rooting (Table 1). Cultures were incubated in dark for one week and then transferred to light at $25^{\circ} \mathrm{C} \pm 2^{\circ} \mathrm{C}$ with a $16 \mathrm{~h}$ photoperiod $\left(50 \mu \mathrm{mol} \cdot \mathrm{m}^{-2} \cdot \mathrm{s}^{-1}\right)$. Test tubes were arranged in a completely randomized design with ten replicates per treatment and the experiment was repeated three times. Destructive root count was performed after six weeks and the number of roots produced by each shoot was recorded. Incidence of callus and hyperhydricity occurrence in rooting cultures was also noted. Data were analyzed using a Mixed Model of the statistical analysis software [19]. Means were separated using Tukey's test and differences were considered significant at $p \leq 0.05$.

\subsection{Acclimatization and Plant Regeneration}

Thirty one in vitro generated plants with a well-developed shoot and root system were transferred to $8 \mathrm{~cm}$ dia. plastic pots containing PRO-MIX (Premier Horticulture Inc., Quakertown, PA). Plants were acclimatized by covering the pots with transparent plastic bags to maintain high relative humidity. After one week, bags were removed and plants were treated with a water soluble 20-20-20 (N-P-K) fertilizer at biweekly intervals. Survival percentage of plantlets was recorded. After four weeks of acclimation, plants were transferred to a greenhouse.

\subsection{DNA Isolation and Quantification}

Actively growing shoot apices of the stock plant and 31 plants produced through micropropagation were harvested and immediately frozen at $-80^{\circ} \mathrm{C}$. Samples were ground in liquid nitrogen and homogenized in a tissue lyser (Qiagen, Valencia, CA) for $2 \mathrm{~min}$ at $30 \mathrm{~Hz}$ to disrupt leaf material. Total genomic DNA was extracted from $500 \mathrm{mg}$ of leaf tissue using a DNeasy Plant Maxi Kit (Qiagen, Valencia, CA). DNA quality was checked on a $1 \%(\mathrm{w} / \mathrm{v})$ agarose gel, and concentration was measured as equivalent of absorbance at $260 \mathrm{~nm}$ using a spectrophotometer (Nano Drop, Wilmington, DE). DNA was diluted to10 ng $\mu^{-1}$ concentration using molecular grade water and stored at $-80^{\circ} \mathrm{C}$ prior to use in marker analyses.

\subsection{PCR Amplification, Microsatellite Detection and Analysis}

The stock plant and 31 micropropagated plants were tested for clonal fidelity using a set of seventeen microsatellite loci cloned and sequenced by Risterucci et al. [12] (Table 2). PCR amplifications were performed using WellRED fluorescent dye-labeled primers (Beckman Coulter, Inc., Fullerton, CA). Reactions were carried out in $25 \mu \mathrm{L}$ volume containing $10 \mathrm{ng}$ genomic DNA, $0.4 \mu \mathrm{M}$ dNTPs, $0.1 \mu \mathrm{M}$ fluorescent-labeled forward and reverse primers, $3.0 \mathrm{mM} \mathrm{MgCl}_{2}$, and $0.1 \mathrm{U}$ Taq polymerase mixed in reaction buffer (pH 8.5). After an initial denaturation at $94^{\circ} \mathrm{C}$ for $5 \mathrm{~min}$, PCR amplification was performed using a Bio-Rad iCycler ver. 1.259 system (Bio-Rad, Hercules, CA, USA) under the following conditions: 30 cycles consisting of $94^{\circ} \mathrm{C}$ for $45 \mathrm{~s}, 55^{\circ} \mathrm{C}$ for $60 \mathrm{~s}$ and $72^{\circ} \mathrm{C}$ for $60 \mathrm{~s}$ with a final extension of $8 \mathrm{~min}$ at $72^{\circ} \mathrm{C}$. The amplified loci were separated by capillary electrophoresis and analyzed on a $\mathrm{CEQ}^{\mathrm{TM}} 8000$ eight-channel capillary genetic analysis system (Beckman Coulter, Fullerton, CA, USA). Fragment sizes were calculated to two decimal places by the $\mathrm{CEQ}^{\mathrm{TM}} 8000$ genetic analysis system, and assessed manually to remove spurious and stutter peaks. Fragment sizes were graphed and alleles were called based on a 1 bp separation. For the UPGMA cluster analysis, marker data was imported into NTSYSpc [20]. Genetic similarity between each pair of micropropagated plant was calculated using the SIMQUAL module using the DICE coefficient of similarity [21]. A dendrogram was generated from the similarity matrix by using the UPGMA procedure in the SAHN module of NTSYSpc. The Free Tree software program [22] was used to perform bootstrapping analysis with a total of 500 repetitions. Bootstrap values greater than $50 \%$ are depicted.

\section{Results}

\subsection{Establishment of Explants and Root Induction}

Shoot proliferation from nodal explants was observed within 4 weeks of culture initiation with a total of 31 shoots being produced from two nodes (Figure 1(a)). Root initiation was observed after three weeks of transfer to rooting media treatments. No root formation was observed in hormone free medium (control). The maximum number of roots ( 6 - 7 roots per shoot) were observed in shoots grown on half strength MS medium containing either $9.8 \mu \mathrm{M}$ IBA or $11.4 \mu \mathrm{M}$ IAA followed by $4.9 \mu \mathrm{M}$ IBA and $10.6 \mu \mathrm{M}$ NAA (Table 1 ). However, shoots grown on media treatments with higher auxin concentrations produced stunted roots (data not shown). 
Table 1. Effect of plant growth regulators on root production of in vitro propagated shoots in "Lucknow 49" guava.

\begin{tabular}{|c|c|}
\hline \multirow{2}{*}{ Medium Treatment $(\mu \mathrm{M})$} & Number of Roots/Explant \\
\hline & (Mean \pm SE) \\
\hline Control & $0^{\mathrm{e}}$ \\
\hline 1/2 MS + NAA (5.3) & $2 \pm 1^{\mathrm{d}}$ \\
\hline 1/2 MS + IBA (4.9) & $4 \pm 1^{\mathrm{b}}$ \\
\hline 1/2 MS + IAA (5.7) & $2 \pm 1^{\mathrm{cd}}$ \\
\hline 1/2 MS + NAA (10.6) & $4 \pm 1^{\mathrm{b}}$ \\
\hline 1/2 MS + IBA (9.8) & $7 \pm 1^{\mathrm{a}}$ \\
\hline 1/2 MS + IAA (11.4) & $6 \pm 1^{\mathrm{a}}$ \\
\hline 1/2 MS + NAA (21.2) & $2 \pm 1^{\mathrm{cd}}$ \\
\hline 1/2 MS + IBA (19.6) & $3 \pm 1^{\mathrm{bcd}}$ \\
\hline 1/2 MS + IAA (22.8) & $3 \pm 1^{\text {bc }}$ \\
\hline
\end{tabular}

Means followed by the same letters are not significantly different at $p \leq 0.05$.
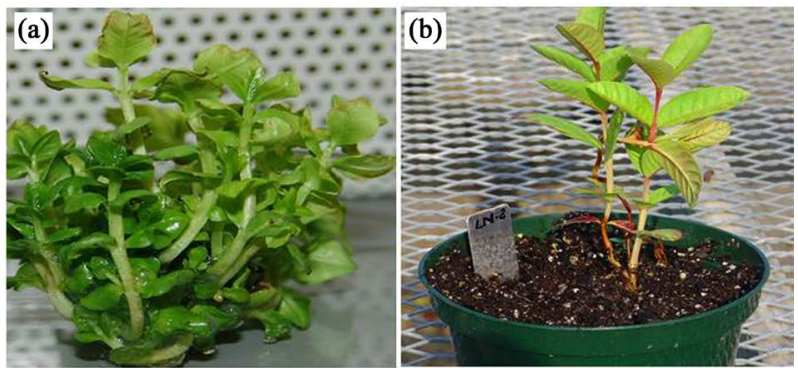

Figure 1. Establishment of micropropagated "Lucknow-49” Psidium guajava: (a) In vitro shoot proliferation from seedling explant on MS medium; (b) Two-month old rooted plant grown in the greenhouse.

\subsection{Plant Regeneration}

Production of new leaves was observed in plants produced through micropropagation after 3 weeks of transfer to potting mix and $100 \%$ survival rate was obtained (Figure 1(b)). Plants were labeled from P2 to P32, of which P27 to P32 exhibited anthocyanin pigmentation.

\subsection{Microsatellite Analysis}

All SSR primers generated amplicons in the 31 micropropagated plants and mother plant. Allele peaks were observed in the same size range as reported by Risterucci et al. [12]. Of the 17 SSRs tested, primers mPgCIR04, mPgCIR09 and mPgCIR16 generated two peaks indicating heterozygosity at these loci (Table 2). Of a total of 544 amplification profiles (32 samples $\times 17$ primer pairs) scored in the study, 448 (82.4\%) were homozygous while 96 (17.6\%) were heterozygous. Comparison of the micropropagated plants to the mother plant showed the presence of the same allele for 16 of the 17 loci tested. However, primer mPgCIR07 generated two alleles among the 31 micropropagated plants. At this locus, six micropropagated plants had an allele that was 1 bp smaller (152 bp) than the parental genotype (153 bp) (Figure 2). The UPGMA dendrogram displayed differences between the micropropagated plants and the mother plant (Figure 3). Of these six plants with the smaller allele, three (P27, P28, and P30) exhibited mutations that affected the phenotype as manifested by anthocyanin pigmentation of the leaves.

\section{Discussion}

Guava (Psidium guajava L.) is commercially propagated by seed. However, average yield is lower than its potential due to the use of seedlings [23]. In addition, genetic purity is not maintained due to segregation and recombination of traits, which has given rise to several cultivars [13]. Clonal propagation offers a solution to this 


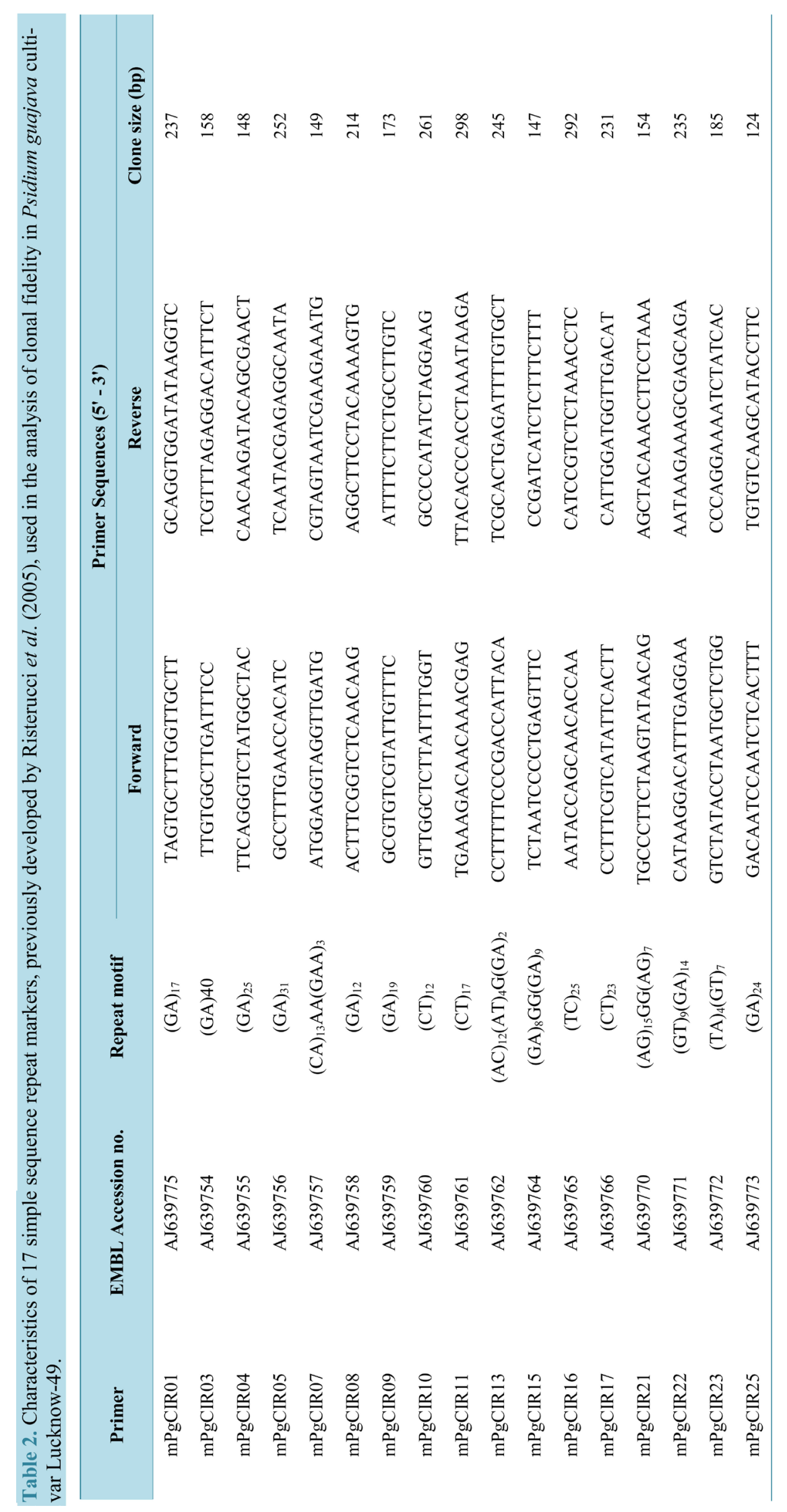




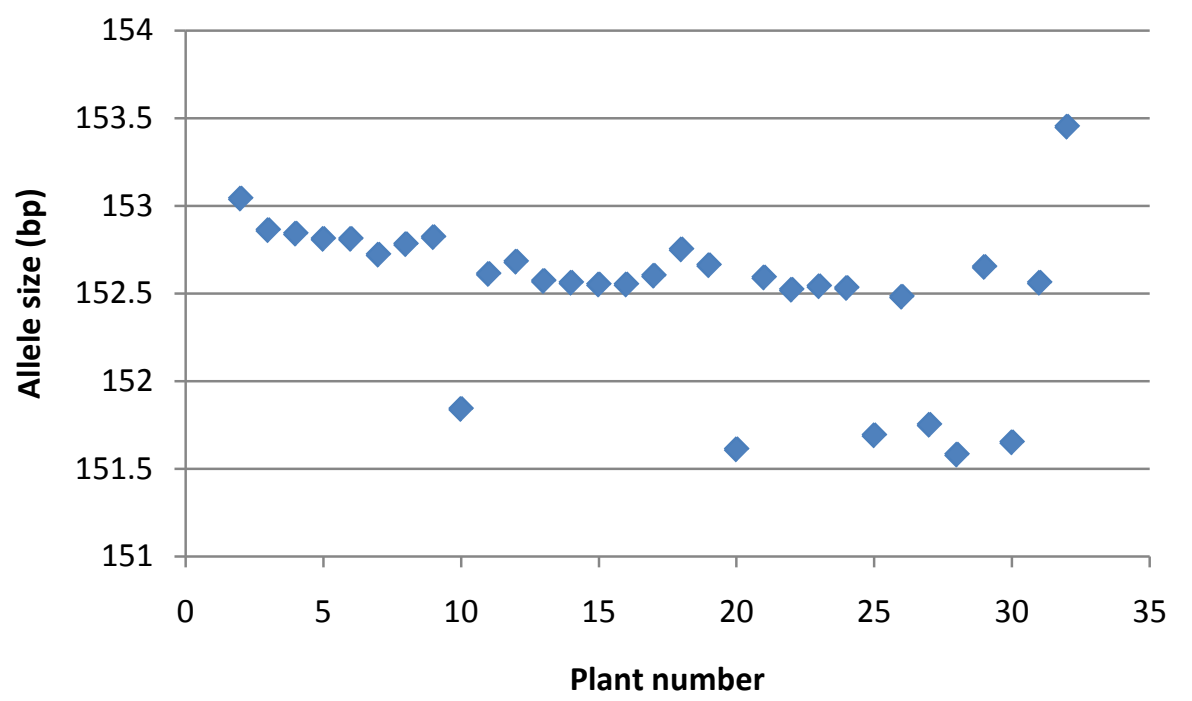

Figure 2. Allele sizes of "Lucknow-49" mother plant and 31 micropropagated Psidium guajava with the microsatellite loci mPgCIR07. Six of the 31 plants tested had an allele size of $152 \mathrm{bp}$.

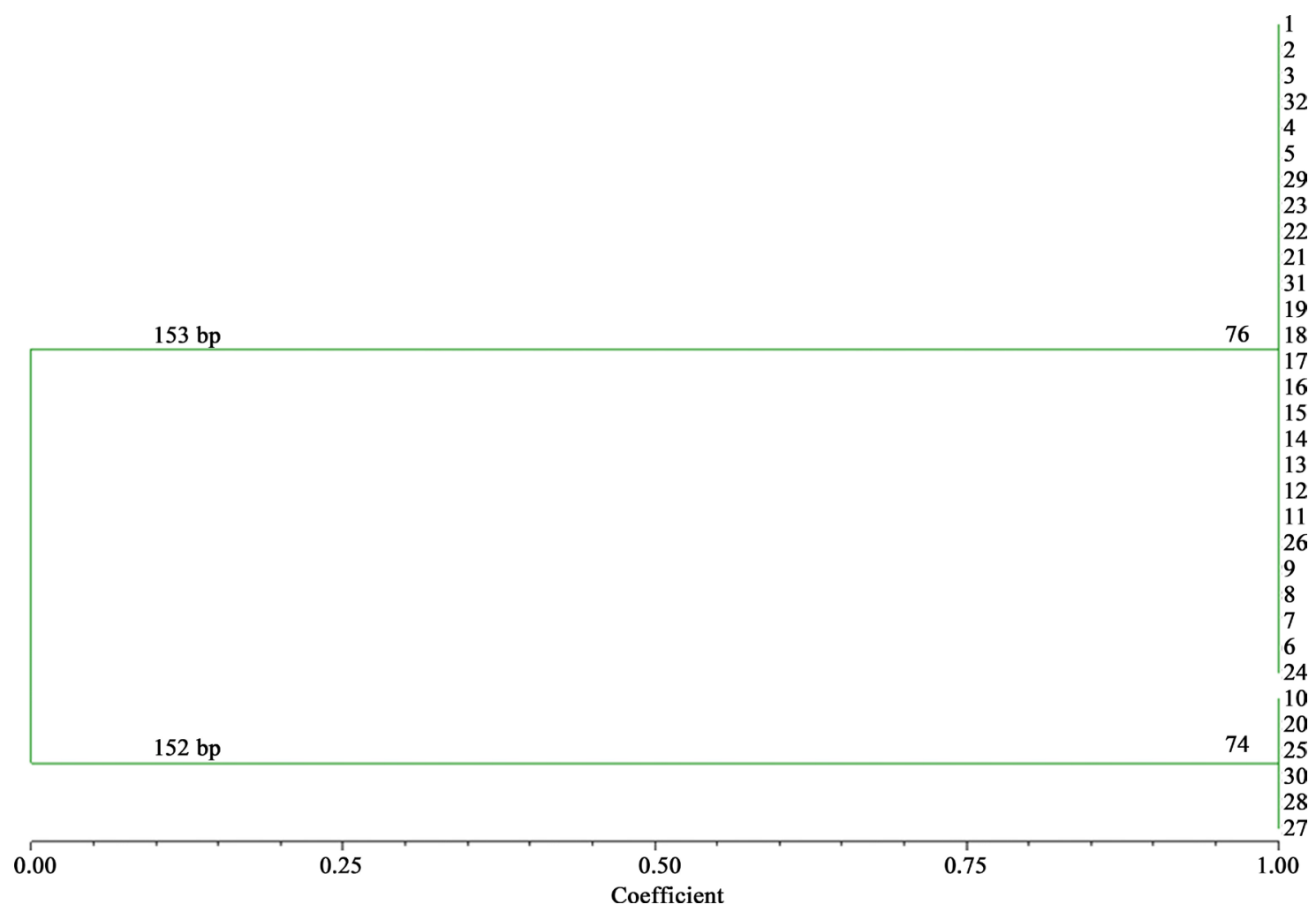

Figure 3. UPGMA dendrogram displaying the genetic relationships of 31 micropropagated Psidium guajava plants (\#2 - 32) and the mother plant (\#1) with the microsatellite loci mPgCIR07.

problem, where outstanding clones could be propagated for commercial plantings allowing uniformity in fruit characteristics, disease resistance, and increased yield within a limited time frame [24]. Successful rooting of in vitro produced shoots is an essential prerequisite for rapid plant production using micropropagation [25]. While root initiation has been tested by various researchers, differential response in various guava cultivars has been noted. Guava cultivars exhibit a differential response in their ability to produce roots from shoot cultures with some cultivars exhibiting poor rooting in medium containing auxins [26]. In our study, the highest number of 
roots was produced from "Lucknow 49" shoots grown on MS media supplemented with IBA and IAA, which resulted in $100 \%$ survival of the plants. Thus, it is paramount to test individual cultivars for their rooting response using various sources and levels of auxins.

Of the 17 loci tested, 16 detected the same allele in plants obtained via micropropagation, while loci mPgCIR07 produced two alleles (Figure 2). Six micropropagated plants had an allele that was 1 bp smaller (152 bp) than the parental genotype (153 bp) at one locus (5.9\%). This is similar to the rate of polymorphism (10\%) detected among micropropagated guava plants from an unlisted cultivar using ISSR markers [1]. While 14 SSRs were homozygous (82.4\%) for the 31 clones and mother plant, three primers (mPgCIR04, mPgCIR09 and mPgCIR16) were heterozygous (17.6\%). In a previous study of genetic diversity assessment of 35 accessions in the US, these loci were shown to be heterozygous for "Lucknow 49" as well [14].

It should be noted that three of the six plants (P27, P28, and P30) that exhibited anthocyanin pigmentation had the smaller allele (152 bp) for loci mPgCIR07. It is possible that a mutation in the anthocyanin pathway could have resulted in enhanced anthocyanin pigmentation, which is a common phenomenon in plants derived from cell culture involving somatic cells. Somaclonal variation can create novel variants with desirable traits, however, may produce plants with diverse phenotypes. The cause of somaclonal variation has not been fully elucidated although plant growth regulators, number of transfers during the culture process and their duration, and stress during tissue culture may enhance the rate of somaclonal variation [27]. Phenotypic variation is genetic or epigenetic in origin [28] and could include differences in chromosome number and sequence changes such as translocations, deletions, insertions, inversions, duplications, and base pair changes [29]. Epigenetic modifications such as differences in DNA methylation, histone modification, and small RNA levels have been reported previously in plant cell cultures [28].

\section{Conclusion}

In this study, a protocol for efficient rooting of "Lucknow 49" shoots and plant regeneration was established, and SSR markers were used to assess the genetic fidelity of micropropagated plants. Information presented in the study indicated that although most micropropagated plants were identical to the mother plant (94.1\%), low variation (5.9\%) was detected. While most mutations have no effect on phenotype, those that do may be problematic if phenotypic uniformity of guava is required.

\section{Acknowledgements}

Facilities provided at Morgan State University and Fort Valley State University are greatly appreciated. The authors thank Ms. Donna Harris for technical help. S.A. Dhekney holds the E.A. Whitney Endowed Professorship in the Department of Plant Sciences.

\section{References}

[1] Liu, X. and Yang, G. (2012) Assessment of Clonal Fidelity of Micro-Propagated Guava (Psidium guajava) Plants by ISSR Markers. Australian Journal of Crop Sciences, 6, 291-295.

[2] Mahattanatawee, K., Manthey, J., Luzio, G., Talcott, S.T., Goodner, K. and Baldwin, E.A. (2006) Total Antioxidant Activity and Fiber Content of Select Florida-Grown Tropical Fruits. Journal of Agricultural Food Chemistry, 54, 73557363. http://dx.doi.org/10.1021/jf060566s

[3] Preece, W.E. (1981) Fruit Nutrient Composition Table. Encyclopedia Britannica, 7, 766.

[4] USDA, NASS (2012) Guavas: 2011 Production up 46 Percent. Hawaii Farm Facts. http://www.nass.usda.gov/Statistics_by_State/Hawaii/Publications/Fruits_and_Nuts/guavaFF.pdf

[5] Nakasone, Y.H. and Paul, R.E. (1998) Tropical Fruits. In: Crop Production Science in Horticulture Series, CAB International, Wallingford, 468.

[6] Abbas, M.M., Javed, M.A., Ishfaq, M. and Alvi, M.A. (2013) Grafting Techniques in Guava (Psidium guajava). Journal of Agricultural Research, 51, 465-470.

[7] Rai, M.K., Asthana, P., Jaiswal, V.S. and Jaiswal, U. (2010) Biotechnological Advances in Guava (Psidium guajava L.): Recent Developments and Prospects for Further Research. Trees, 24, 1-12. http://dx.doi.org/10.1007/s00468-009-0384-2

[8] Cullis, C.A. (1992) The Molecular Biology of Plant Cells and Cultures. In: Fowler, M.W. and Warren, G.S., Eds., 
Plant Biotechnology, Pergamon Press, Oxford, 19-32. http://dx.doi.org/10.1016/b978-0-08-034731-8.50009-6

[9] Phillips, R.L., Kaeppler, S.M. and Othoft, P. (1994) Genetic Stability of Plant Tissue Cultures. Break down of Normal Controls. Proceedings of the National Academy of Sciences, 91, 5222-5226. http://dx.doi.org/10.1073/pnas.91.12.5222

[10] Martins, M., Sarmento, D. and Oliveira, M.M. (2004) Genetic Stability of Micropropagated Almond Plantlets as Assessed by RAPD and ISSR Markers. Plant Cell Reports, 23, 492-496. http://dx.doi.org/10.1007/s00299-004-0870-3

[11] Saker, M.M., Bekheet, S.A., Taha, H.S., Fahmy, A.S. and Moursy, H.A. (2000) Detection of Somaclonal Variations in Tissue Culture-Derived Date Palm Plants Using Isoenzyme Analysis and RAPD Fingerprints. Biologia Plantarum, 43, 347-351. http://dx.doi.org/10.1023/A:1026755913034

[12] Risterucci, A.M., Duval, M.F., Rohde, W. and Billotte, N. (2005) Isolation and Characterization of Microsatellite Loci from Psidium guajava L. Molecular Ecology Notes, 5, 745-748. http://dx.doi.org/10.1111/j.1471-8286.2005.01050.x

[13] Kanupriya, P., Latha, M., Aswath, C., Reddy, L., Padmakar, B., Vasugi, C. and Dinesh, M.R. (2011) Cultivar Identification and Genetic Fingerprinting of Guava (Psidium guajava) Using Microsatellite Markers. International Journal of Fruit Science, 11, 184-196. http://dx.doi.org/10.1080/15538362.2011.578521

[14] Sitther, V., Zhang, D., Harris, D.L., Yadav, A.K., Zee, F.T., Meinhardt, L.W. and Dhekney, S.A. (2014) Genetic Characterization of Guava (Psidium guajava L.) Germplasm in the United States Using Microsatellite Markers. Genetic Resource and Crop Evolution, 61, 829-839. http://dx.doi.org/10.1007/s10722-014-0078-5

[15] Kadam, D.M., Kaushik, P. and Kumar, R. (2012) Evaluation of Guava Products Quality. International Journal of Food Sciences and Nutrition Engineering, 2, 7-11. http://dx.doi.org/10.5923/j.food.20120201.02

[16] Jain, P.C. and Bhargava, M.C. (2007) Entomology: Novel Approaches. New India Publishing, New Delhi.

[17] Murashige, T. and Skoog, F. (1962) A Revised Medium for a Rapid Growth and Bioassays with Tobacco Tissue Cultures. Physiologia Planatarium, 15, 473-497. http://dx.doi.org/10.1111/j.1399-3054.1962.tb08052.x

[18] Sitther, V., Harris, D.L., Dhekney, S.A., Bai, J.A., Baldwin, E.A. and Yadav, A.K. (2011) Total Phenol Content of Guava Fruit and Development of an in Vitro Regeneration Protocol Amenable to Genetic Improvement. International Journal of Food Safety, Nutrition and Public Health, 4, 225-236. http://dx.doi.org/10.1504/IJFSNPH.2011.044625

[19] SAS (2003) Users' Guide, Statistics. Statistical Analysis System, Inc., Raleigh.

[20] Rohlf, F.J. (2008) NTSYSpc: Numerical Taxonomy System, ver. 2.20. Exeter Publications, Setauket.

[21] Nei, M. and Li, W.H. (1979) Mathematical Model for Studying Genetic Variation in Terms of Restriction Endonucleases. Proceedings of the National Academy of Sciences, 76, 5269-5273. http://dx.doi.org/10.1073/pnas.76.10.5269

[22] Hampl, V., Pavlícek, A. and Flegr, J. (2001) Construction and Bootstrap Analysis of DNA Fingerprinting-Based Phylogenetic Trees with a Freeware Program Free Tree: Application to Trichomonad Parasites. International Journal of Systematic and Evolutionary Microbiology, 51, 731-735. http://dx.doi.org/10.1099/00207713-51-3-731

[23] Ali, N., Mulwa, R.M.S., Norton, M.A. and Skirvin, R.M. (2003) Micropropagation of Guava (Psidium guajava L.). Journal of Horticultural Science and Biotechnology, 78, 739-741.

[24] Singh, M., Jaiswal, U. and Jaiswal, V.S. (2004) In Vitro Regeneration and Improvement in Tropical Fruit Trees: An Assessment. In: Srivastava, P.S., Narula, A. and Srivastava, S., Eds., Plant Biotechnology and Molecular Markers, Anamanya Publishers, New Delhi, 228-243.

[25] Pati, P.K., Rath, S.P., Sharma, M., Sood, A. and Ahuja, P.S. (2006) In Vitro Propagation of Rose-A Review. Biotechnology Advances, 24, 94-114. http://dx.doi.org/10.1016/j.biotechadv.2005.07.001

[26] Joshee, N., Mutua, M., Zee, F. and Yadav, A.K. (2004) In Vitro Shoot Bud Induction and Plantlet Regeneration in Guava as Influenced by Genotype. Acta Horticulturae (ISHS), 632, 279-285. http://dx.doi.org/10.17660/actahortic.2004.632.36

[27] Bairu, M.W., Aremu, A.O. and Van Staden, J. (2011) Somaclonal Variation in Plants: Causes and Detection Methods. Plant Growth Regulation, 63, 147-173. http://dx.doi.org/10.1007/s10725-010-9554-x

[28] Miguel, C. and Marum, L. (2011) An Epigenetic View of Plant Cell Cultured in Vitro: Somaclonal Variation and Beyond. Journal of Experimental Botany, 62, 3713-3725. http://dx.doi.org/10.1093/jxb/err155

[29] Wang, Q.-M. and Wang, L. (2012) An Evolutionary View of Plant Tissue Culture: Somaclonal Variation and Selection. Plant Cell Reports, 31, 1535-1547. http://dx.doi.org/10.1007/s00299-012-1281-5 